\title{
The Quality Reference Framework for MOOC Design
}

\author{
Citation for published version (APA):
}

Stracke, C. M. (2019). The Quality Reference Framework for MOOC Design. In M. Scheffel, J. Broisin, V. Pammer-Schindler, A. loannou, \& J. Schneider (Eds.), Transforming Learning with Meaningful Technologies: 14th European Conference on Technology Enhanced Learning, EC-TEL 2019, Delft, The Netherlands, September 16-19, 2019, Proceedings (pp. 673-677). Springer International Publishing AG. Lecture Notes in Computer Science (LNCS) series Vol. 11722 https://doi.org/10.1007/978-3-030-29736-7_64

\section{DOI:}

10.1007/978-3-030-29736-7_64

Document status and date:

Published: 01/01/2019

Document Version:

Publisher's PDF, also known as Version of record

\section{Document license:}

CC BY-NC-ND

Please check the document version of this publication:

- A submitted manuscript is the version of the article upon submission and before peer-review. There can be important differences between the submitted version and the official published version of record. People interested in the research are advised to contact the author for the final version of the publication, or visit the DOI to the publisher's website.

- The final author version and the galley proof are versions of the publication after peer review.

- The final published version features the final layout of the paper including the volume, issue and page numbers.

Link to publication

\section{General rights}

Copyright and moral rights for the publications made accessible in the public portal are retained by the authors and/or other copyright owners and it is a condition of accessing publications that users recognise and abide by the legal requirements associated with these rights.

- Users may download and print one copy of any publication from the public portal for the purpose of private study or research.

- You may not further distribute the material or use it for any profit-making activity or commercial gain

- You may freely distribute the URL identifying the publication in the public portal.

If the publication is distributed under the terms of Article 25fa of the Dutch Copyright Act, indicated by the "Taverne" license above, please follow below link for the End User Agreement:

https://www.ou.nl/taverne-agreement

Take down policy

If you believe that this document breaches copyright please contact us at:

pure-support@ou.nl

providing details and we will investigate your claim.

Downloaded from https://research.ou.nl/ on date: 26 Apr. 2023 


\section{Christian M. Stracke}

\section{The Quality Reference Framework for MOOC Design}




\title{
The Quality Reference Framework for MOOC Design
}

\author{
by Christian M. Stracke (2019)
}

\section{Citation:}

Stracke, C. M. (2019). The Quality Reference Framework for MOOC Design. In M. Scheffel et al. (Eds.), Proceedings of the 14th European Conference on Technology Enhanced Learning (EC-TEL 2019), LNCS 11722 (pp. 673-677). doi:10.1007/978-3-030-29736-7_64

[also online available at: http://www.opening-up.education/publications]

\section{Contact:}

Dr. Christian M. Stracke

ICDE Chair in OER

Associate Professor for Open Education and Innovation

Open University of the Netherlands

Adjunct Professor, Korean National Open University

Advisory Professor, East China Normal University

ORCID: 0000-0001-9656-8298

Christian.Stracke@OU.NL

http://www.opening-up.education

http://www.learning-innovations.eu

http://www.ICORE-online.org

(C) Christian M. Stracke

This article is published under the Creative Commons licence "BY-NC-ND 4.0" (Attribution - Non-Commercial - No Derivate 4.0)

The full licence (legal code) can be read online here:

<http://creativecommons.org/licenses/by-nc-nd/4.0/legalcode>

You are free to share the work, i.e. to copy and redistribute the material in any medium or format, under the following conditions:

1. Attribution -

2. NonCommercial -

3. NoDerivates 


\title{
The Quality Reference Framework for MOOC Design
}

\author{
Christian M. Stracke ${ }^{(\bowtie)}(\mathbb{D}$ \\ Open University of the Netherlands, Heerlen, The Netherlands \\ christian.stracke@ou.nl
}

\begin{abstract}
This paper introduces "The Quality Reference Framework (QRF) for the Quality of MOOCs". It was developed by the European Alliance for the Quality of Massive Open Online Courses (MOOCs), called MOOQ that could involve in the QRF finalization more than 10,000 MOOC learners, designers, facilitators and providers. The QRF consists of three dimensions: Phases, Perspectives and Roles. It includes two quality instruments: the QRF Key Quality Criteria for MOOC experts and QRF Quality Checklist for MOOC beginners.
\end{abstract}

Keywords: Quality Reference Framework - Massive Open Online Courses · MOOC design · MOOC quality · QRF Key Quality Criteria · QRF Quality Checklist

\section{The QRF - Based on Truly International Collaboration}

"The Quality Reference Framework (QRF) for the Quality of MOOCs" [13] was developed by the European Alliance for the Quality of Massive Open Online Courses (MOOCs), called MOOQ. MOOQ was started due to the huge demand for improving the quality of MOOCs from research [7-10, 16, 17] and from practice [4, 6, 10, 11]. Overall, MOOQ could address and reach out to more than 100,000 MOOC learners, designers, facilitators and providers through dissemination and exploitation activities. The main objective of MOOQ was the development of the QRF that was finalized and published in the year 2018 after more than three years of revisions and refinements [13]. In close cooperation with leading European and international institutions and associations, MOOQ could involve in the QRF finalization more than 10,000 MOOC learners, designers, facilitators and providers through divers means including the Mixed Methods research with the Global MOOC Quality Survey (GMQS), MOOQ presentations and workshops at regional and international conferences and communication and collaboration in traditional and social media $[12,14]$.

\section{The Three Dimensions of the QRF}

The QRF consists of three dimensions: 1. Phases, 2. Perspectives and 3. Roles (see below). These three dimensions were carefully selected, discussed and agreed with all MOOC stakeholder groups to cover the different views, requirements and responsibilities during the lifetime of a MOOC. They are mainly based on the results from the 
Mixed Methods research by MOOQ [12, 14, 15]: That included the realization and evaluation of the first Global MOOC Quality Surveys (for MOOC learners, designers and facilitators), the 27 semi-structured interviews conducted with MOOC experts (designers, facilitators and providers) and the MOOQ Workshops at eight international conferences (ICDE 2015 in Sun City, South Africa, OE Global 2016 in Krakow, Poland, EC-TEL 2016 in Lyon, France, OE Global 2017 in Cape Town, South Africa, IEEE EDUCON 2017 in Athens, Greece, ICALT 2017 in Timisoara, Romania, EARLI 2017 in Tampere, Finland and EC-TEL 2017 in Tallinn, Estonia). Furthermore, the QRF has adapted the International learning quality standard ISO/IEC 40180 (former ISO/IEC 19796-1) to the specific requirements and needs for MOOCs.

The first dimension of the QRF is called "Phases" and consists of five phases that normally overlap and can be repeated in iterative cycles:

Analysis (A): identify and describe requirements, demands and constraints

Design (D): conceptualise and design the MOOC

Implementation (I): implement a MOOC draft and finalize it through testing

Realization (R): realise and perform the MOOC including support and assessment

Evaluation (E): define, run and analyse the evaluation and improve the MOOC

The second dimension of the QRF is called "Perspectives" and distinguishes three perspectives that have to be addressed and focused during the different phases:

Pedagogical (P): how has the MOOC to be designed and developed?

Technological (T): how has the MOOC to be implemented and realized?

Strategic (S): how has the MOOC to be managed and offered?

The third dimension of the QRF is called "Roles" and covers three roles and indicates their involvement and responsibilities in relation to the phases and perspectives:

Designer: Designer includes content experts, content authors, instructional designers, experts for MOOC platforms, technology-enhanced learning and digital media as well as any others who may contribute to the design of a MOOC.

Facilitator: Facilitator includes the pedagogical facilitators and experts with content knowledge (such as moderators, tutors, teaching assistants) who manage forum, provide feedback and monitor learning progress, the technical facilitators (such as technical support for learners) as well as others who may contribute to support participants in their learning process in a MOOC.

Provider: Provider includes the (internal and external) MOOC providers, the technical providers (such as technology providers, programmers, software designers and developers), managers, communication and marketing staff as well as others who are involved in the decision-making processes leading to the delivery of a MOOC. 


\section{The Structure of the QRF and Its Usage and Benefits}

The QRF presents the quality framework as general template to be adapted together with two applications: the QRF Key Quality Criteria and the QRF Checklist. The general framework of the QRF is a table that has to be adapted and completed. It integrates the three dimensions into a holistic quality framework that can be used for different purposes and by different user groups answering the needs identified by current research $[1-3,5]$. To demonstrate the opportunities and to provide an easier start for its usage, the QRF offers and presents two instruments for two user groups: the QRF Key Quality Criteria for MOOC experts and the QRF Checklist for MOOC beginners.

The QRF Key Quality Criteria are provided in a table for experienced MOOC designers, facilitators and providers. They are intended as support for analysing, designing, implementing, realizing and evaluating a MOOC. The QRF Key Quality Criteria are defined as action items for potential activities in the different processes.

The QRF Quality Checklist presents leading questions for all three QRF dimensions. They are intended for both, beginners and experts in the MOOC design and development. Therefore, the QRF Quality Checklist serves as a starting point and a reminder on critical issues to be addressed. It complements the QRF Key Quality Criteria that defines the phases and processes of the MOOC design and development.

To use the QRF, it is most important to adapt it to own specific needs. MOOC designers, facilitators and providers have to select and define the relevant phases including their perspectives and roles according to their own situation, learning objectives, target groups, context and further conditions. Such adaptations should be documented to inform all involved stakeholders as well as to allow their review in the evaluation and further improvement of the MOOCs.

There are four core benefits of the QRF: First, the QRF provides a generic framework that can be adapted to each specific context. Second, the QRF identifies key quality criteria for better orientation on the MOOC design. Third, the QRF presents a checklist for the quality development and evaluation of MOOCs. And fourth, the QRF enables a continuous improvement cycle for MOOC design and provision.

\section{Innovative Impact and Conclusions}

The QRF has already achieved direct short-term innovative impact: It was used for the design and implementation for the development of two MOOCs as pilot implementations. They were following different pedagogical approaches (one xMOOC as traditional online course and one cMOOC for collaborative online learning). In both cases, the usage of the QRF was considered as very helpful by the MOOC designers and leading to reduced efforts due to the design support provided by the QRF.

Thus, the QRF will achieve long term innovative impact for the development of MOOCs, too. In addition, the QRF will also help MOOC providers and MOOC facilitators to improve the provision and facilitation of future MOOCs: The QRF Key Quality Criteria and the QRF Quality Checklist are addressing all stakeholder groups offering support for beginners as well as experts. 
The QRF can be downloaded for free with an open Creative Commons license CCBY from: www.MOOC-quality.eu/QRF. It is the first and unique guideline for the quality of MOOCs based on Mixed Methods research and involvement of the global MOOC community. The QRF Quality Checklist offers MOOC beginners an easy tool for the design and implementation of a first MOOC. And the QRF Key Quality Criteria support MOOC experts to continuously evaluate and improve their MOOC designs. Thus, the QRF will improve the future MOOCs and online learning in general.

\section{References}

1. Alario-Hoyos, C., Estévez-Ayres, I., Pérez-Sanagustín, M., Delgado Kloos, C., FernándezPanadero, C.: Understanding learners' motivation and learning strategies in MOOCs. IRRODL 18(3), 119-137 (2017). https://doi.org/10.19173/irrodl.v18i3.2996

2. Bayeck, R.Y.: Exploratory study of MOOC learners' demographics and motivation: the case of students involved in groups. Open Praxis 8(3), 223-233 (2016). https://doi.org/10.5944/ openpraxis.8.3.282

3. Brooker, A., Corrin, L., de Barba, P., Lodge, J., Kennedy, G.: A tale of two MOOCs: how student motivation and participation predict learning outcomes in different MOOCs. AJET 34(1), 73-87 (2018). https://doi.org/10.14742/ajet.3237

4. Conole, G.: Designing effective MOOCs. Educ. Media Int. 52(4), 239-252 (2015). https:// doi.org/10.1080/09523987.2015.1125989

5. Glass, C.R., Shiokawa-Baklan, M.S., Saltarelli, A.J.: Who takes MOOCs? New Dir. Inst. Res. 2015(167), 41-55 (2016). https://doi.org/10.1002/ir.20153

6. Lowenthal, P., Hodges, C.: In search of quality: using quality matters to analyze the quality of massive, open, online courses (MOOCs). IRRODL 16(5), 83-101 (2015). https://doi.org/ 10.19173/irrodl.v16i5.2348

7. Margaryan, A., Bianco, M., Littlejohn, A.: Instructional quality of massive open online courses (MOOCs). CAE 80, 77-83 (2015). https://doi.org/10.1016/j.compedu.2014.08.005

8. Reich, J.: Rebooting MOOC research. Science 347(6217), 34-35 (2015). https://doi.org/10. 1126/science. 1261627

9. Stracke, C.M.: Quality frameworks and learning design for open education. IRRODL 20(2), 180-203 (2019). https://doi.org/10.19173/irrodl.v20i2.4213

10. Stracke, C.M.: The quality of MOOCs: how to improve the design of open education and online courses for learners? In: Zaphiris, P., Ioannou, A. (eds.) LCT 2017. LNCS, Part I, vol. 10295, pp. 285-293. Springer, Cham (2017). https://doi.org/10.1007/978-3-319-58509-3_23

11. Stracke, C.M.: Open education and learning quality. In: Proceedings of the 2017 IEEE EDUCON, pp. 1044-1048 (2017b). https://doi.org/10.1109/educon.2017.7942977

12. Stracke, C.M., Tan, E.: The quality of open online learning and education. In: Kay, J., Luckin, R. (eds.) Proceedings of the ICLS 2018, pp. 1029-1032 (2018). http://hdl.handle. net/1820/9909

13. Stracke, C.M., et al.: Quality Reference Framework (QRF) for the Quality of Massive Open Online Courses (MOOCs) (2018). www.mooc-quality.eu/QRF

14. Stracke, C.M., et al.: Gap between MOOC designers' and MOOC learners' perspectives on interaction and experiences in MOOCs. In: Chang, M., Chen, N.-S., Huang, R., Kinshuk, K.M., Murthy, S., Sampson, D.G. (eds.) Proceedings of the 18th IEEE ICALT, pp. 1-5 (2018). https://doi.org/10.1109/icalt.2018.00007 
15. Stracke, C.M., et al.: The quality of open online education. In: Proceedings of the 2017 IEEE EDUCON, pp. 1712-1715 (2017). https://doi.org/10.1109/educon.2017.7943080

16. Veletsianos, G., Shepherdson, P.: A systematic analysis and synthesis of the empirical MOOC literature published in 2013-2015. IRRODL 17(2), 198-221 (2016). https://doi.org/ 10.19173/irrodl.v17i2.2448

17. Zawacki-Richter, O., Bozkurt, A., Alturki, U., Aldraiweesh, A.: What research says about MOOCs. IRRODL 19(1), 242-259 (2018). https://doi.org/10.19173/irrodl.v19i1.3356 